\title{
Morphophysiological characteristics of guanandi fruit and seeds during ripening and harvesting time
}

\author{
Rosemeire Carvalho da Silva( ${ }^{(1)}$, Elisa Serra Negra Vieira ${ }^{(2)}$ and Maristela Panobianco(3)
}

\begin{abstract}
(1)Instituto Federal do Paraná, Campus Paranavaí, Rua José Felipe Tequinha, no 1.400, Jardim das Nações, CEP $87703-536$ Paranavaí, PR, Brazil. E-mail: rosemeire.silva@ifpr.edu.br (2)Embrapa Florestas, Estrada da Ribeira, Km 11, Guaraituba, Caixa Postal 319, CEP 83411-000 Colombo, PR, Brazil. E-mail: elisa.vieira@embrapa.br ${ }^{(3)}$ Universidade Federal do Paraná, Departamento de Fitotecnia e Fitossanitarismo, Rua dos Funcionários, no 1.540, Juvevê, CEP 80035-050 Curitiba, PR, Brazil. E-mail: maristela@ufpr.br
\end{abstract}

Abstract - The objective of this work was to determine the relationship of the morphological and physiological characteristics of guanandi (Calophyllum brasiliense) fruit and seeds with ripening and harvesting time. The reproductive cycle of a native plant population, located in the coast of the state of Paraná, Brazil, was monitored from anthesis until fruit dispersion, during three years. Monthly harvests were performed, and the morphological and physical aspects (color, size, dry mass, and moisture content) of fruit and embryos were evaluated, as well as the physiological ones (germination and vigor) of seeds. The ripening process of guanandi seeds occurred between 200 and 240 days after anthesis (DAA), with anthesis peak in February and fruit dispersion in October. The maximum dry matter mass accumulation was not synchronized with the maximum physiological potential of the seeds. Germination potential was reached close to the middle of the maturation process, and maximum vigor at the end of the cycle. Fruit external color did not change from 110 DAA onwards. The morphological characteristics related to harvesting time are fruit pulp and embryo weakly adherent to the endocarp and to the tegument, respectively, as well as the dark-brown color of these tissues.

Index terms: Calophyllum brasiliense, physiological maturity, reproductive phenology, vigor.

\section{Características morfofisiológicas dos frutos e das sementes de guanandi durante a maturação e o ponto de coleta}

\begin{abstract}
Resumo - O objetivo deste trabalho foi determinar a relação das características morfológicas e fisiológicas do fruto e da semente de guanandi (Calophyllum brasiliense) com a maturação e o ponto de coleta das sementes. O ciclo reprodutivo de uma população de plantas nativas, localizada no litoral do Estado do Paraná, foi monitorado da antese até a dispersão dos frutos, durante três anos. Realizaram-se coletas mensais, tendo-se avaliado aspectos morfológicos e físicos (cor, tamanho, massa de matéria seca e teor de água) dos frutos e dos embriões, bem como os fisiológicos (germinação e vigor) das sementes. O processo de maturação das sementes de guanandi ocorreu entre 200 e 240 dias após antese (DAA), com pico da antese em fevereiro e dispersão dos frutos em outubro. O máximo acúmulo de massa de matéria seca não esteve sincronizado com o máximo potencial fisiológico das sementes. O potencial germinativo foi atingido próximo à metade do processo de maturação, e o máximo vigor no final do ciclo. Não houve mudanças na coloração externa dos frutos a partir de 110 DAA. As características morfológicas relacionadas ao ponto de coleta são a fraca adesão da polpa do fruto e do embrião ao endocarpo e ao tegumento, respectivamente, além da coloração marromescura desses tecidos.
\end{abstract}

Termos para indexação: Calophyllum brasiliense, maturidade fisiológica, fenologia reprodutiva, vigor.

\section{Introduction}

Guanandi (Calophyllum brasiliense Cambess) of the family Calophyllaceae ex Clusiaceae (Syn. Guttiferae) is a wild species native to the Atlantic Forest. It is considered non-endemic and promising for commercial exploitation, since its wood has very good quality and important chemical compounds for the chemical and pharmaceutical areas (Noldin et al., 2006; Oliveira \& Joly, 2010; Schultz, 2011).

An important factor to be considered for harvesting high-quality seeds is the ripening process, which depends on the species and on the producing region. The main modifications observed during this process are related to seed moisture content, dry matter, size, and physiological potential (germination and vigor), 
which, together with morphological characteristics, allow identifying physiological ripeness and the ideal time for harvesting (Barbosa et al., 2015; Marcos-Filho, 2015). When seeds are harvested at an inappropriate stage, their physiological quality is compromised, which will affect all future events, such as germination, seedling production, and, especially, storage potential (Matheus et al., 2011; Carvalho \& Nakagawa, 2012; Marcos-Filho, 2015). Moreover, during the ripening process, seeds usually become more tolerant to water losses because of the accumulation of dry matter (Marcos-Filho, 2015). In recalcitrant seeds, such as those of guanandi (Carvalho et al., 2006), which present lower longevity due to the incapacity of tolerating water losses, this is even more significant.

To extend the conservation period of seeds, particularly of recalcitrant species, harvest must be carried out the closest possible to physiological ripeness, i.e., when the maximum reserve accumulation and probable maximum physiological potential are reached (Barbosa et al., 2015).

Knowledge of the ripening process, as well as the determination of the physiological ripeness point, can be used in the wild seed technology area for improvements in, for example, protocols to conduct germination tests, seed preservation, sanity, seedling production, and genetic breeding. However, considering the wide diversity of wild species, the number of works on these issues is still modest. Among the wild species studied, mostly with recalcitrant seeds, stand out: Eugenia uniflora L. (Avila et al., 2009), E. pyriformis Cambess (Lamarca et al., 2013), Inga striata Benth (Mata et al., 2013), and I. vera Willd. (Caccere et al., 2013).

Specifically for guanandi seeds, the researches in this area focus on clarifying topics related to dormancy (Vásquez-Carballo et al., 2004), germination methods (Nery et al., 2007), and conservation (Silva et al., 2014). However, the scarceness of specific parameters to help identifying the ideal time for seed harvesting may hinder the progress of these works, as reported by Sorol et al. (2015) in a study about drying and conserving guanandi seeds.

The objective of this work was to determine the relationship of the morphological and physiological characteristics of guanandi fruit and seeds with ripening and harvesting time.

\section{Materials and Methods}

The study was carried out from February to October, during three consecutive years $(2013,2014$, and 2015), using a sample composed of 15 guanandi trees from a population of native forest plants located in the municipality of Antonina, in the coast of the state of Paraná, Brazil. The monitored trees were divided into three groups, with approximately $3.5 \mathrm{~km}$ between the first and the third. The first group was concentrated in an area of approximately $1,200 \mathrm{~m}^{2}$, close to the coordinates $25^{\circ} 22^{\prime} 57^{\prime \prime} \mathrm{S}, 48^{\circ} 46^{\prime} 59^{\prime \prime} \mathrm{W}$; the second, in an area of approximately $300 \mathrm{~m}^{2}$, at the coordinates $25^{\circ} 21^{\prime} 42^{\prime \prime} \mathrm{S}, 48^{\circ} 46^{\prime} 11^{\prime \prime} \mathrm{W}$; and the third, also in an area of approximately $1,200 \mathrm{~m}^{2}$, at $25^{\circ} 21^{\prime} 7 " \mathrm{~S}, 48^{\circ} 46^{\prime} 20^{\prime \prime} \mathrm{W}$. The climate of the region is classified as $\mathrm{Cfa}$, according to Köppen-Geiger. The averages of temperature and monthly accumulated rainfall during the experimental period are shown in Figure 1.

The selected plants were monitored for 15-30 days in order to identify the beginning of the reproductive period, defined as the occurrence of floral buds. Once the beginning of this period was verified, plants were monitored every 7 to 10 days, until $50 \%$ of the flowers were in anthesis. From then on, the development of fruit and seeds was checked through monthly harvesting, until complete fruit dispersal.

The ripening process was monitored by evaluating the morphological and physical characteristics of fruit and embryos (color, moisture content, and dry matter), as well as the physiological characteristics of seeds (germination and vigor).

During each harvest, 100 to 150 fruit (5 to 25 per tree) were harvested from plants in the reproductive periodfruit. The harvested fruit were taken to the seed laboratory of the Department of Crop Science and Phytosanitary Measures of Universidade Federal do Paraná, washed under running water, and then dried with a paper towel. After this procedure, four replicates of five randomly chosen fruit were evaluated as to their external (epicarp) and internal (endocarp) color, as well as to their size - vertical and horizontal diameters of fruit and embryos (cotyledons and embryonic axis) -, which was measured with the aid of a $0.1-\mathrm{mm}$ digital caliper. For the vertical diameter of fruit, the ends of the caliper were placed at the insertion point of the stalk and at its opposite apex; and, for the horizontal diameter, the middle portion of the fruit was measured. In the case of the embryos, the endocarp, tegument,

Pesq. agropec. bras., Brasília, v.53, n.2, p.212-220, Feb. 2018 DOI: $10.1590 / \mathrm{S} 0100-204 X 2018000200010$ 
and endosperm were removed (when present) until the embryo was bare; then, the vertical diameter was measured from the apex of the embryonic axis to its opposite apex, and the horizontal diameter, in the middle portion, from one cotyledon to the other, so that the suture line of the cotyledons remained centered. During the ripening process, mainly at the initial stages, the aid of a stereomicroscope was necessary to visualize the embryos; however, their diameters were not measured at this stage, nor was their dry matter mass determined, since it was not possible to obtain precise measures for all sampled embryos.

In order to determine the dry matter mass of fruit, a sample of 20 fruit divided into four replicates was used. The fruit were carefully separated into sections and weighed on an analytical scale $(0.001 \mathrm{~g})$ in order to determine their fresh matter mass, then placed on Kraft paper and taken to an oven with forced-air circulation at $65^{\circ} \mathrm{C}$, until obtaining a constant mass. In addition, a total of 20 embryos, divided into four replicates, were extracted from their respective fruit without their endocarp; after their mass was obtained, they were also placed on Kraft paper and taken to a forced-air circulation oven, following the aforementioned procedure. The fruit were separated into sections to facilitate the water loss of their internal parts, mainly of the structures that are stuck to the woody endocarp. In order to minimize fresh mass losses, this procedure was performed as quickly as possible, in a period of 4 min maximum, based on the recommendations to determine the moisture content of large seeds, according to the rules for seed analysis in Brazil (Brasil, 2009).

The moisture content in the embryos was evaluated in two replicates of five embryos, which were placed in aluminum capsules and taken to an oven at 101$105^{\circ} \mathrm{C}$ for 17 hours; data were obtained on a wet basis, according to recommendations (Brasil, 2009).

Germinating power was obtained with five replicates of ten embryos, distributed on four paper towel sheets and dampened with water at a ratio 2.5 times the dry matter mass of the paper substrate. After their seed coat was removed (Silva et al., 2014), the embryos were placed in a Mangelsdorf-type germinator at $30^{\circ} \mathrm{C}$. Evaluations were performed weekly until constant germination.

Seed vigor was determined together with the germination test, through the germination rate index (Maguire, 1962) and the first germination count (Silva et al., 2014).

The experimental design was completely randomized, and data homogeneity was analyzed by

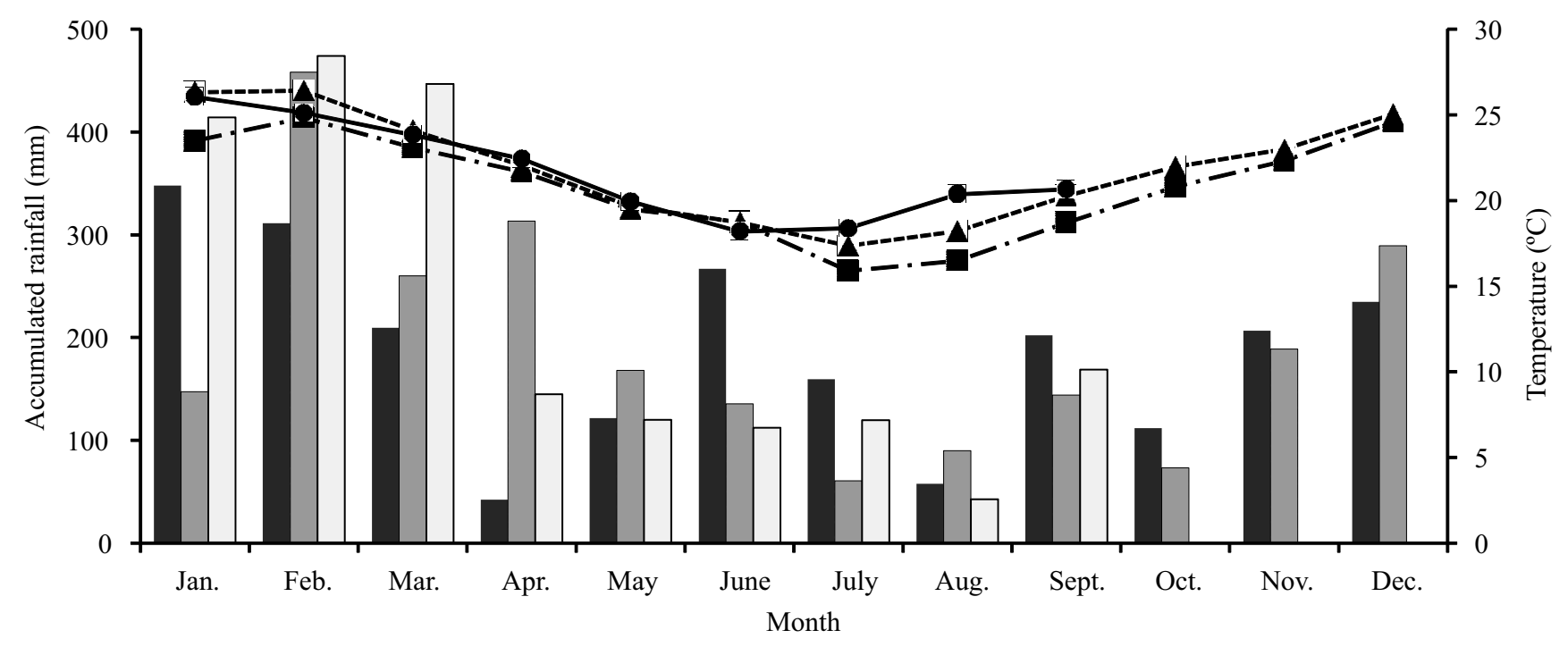

\begin{tabular}{|c|c|c|}
\hline $\begin{array}{l}\text { Rainfall } 2013 \\
\text { _ _ } \cdot \text { Temperature } 2013\end{array}$ & $\begin{array}{l}\square \text { Rainfall } 2014 \\
\text {---A--- Temperature } 2014\end{array}$ & $\begin{array}{l}\square \text { Rainfall } 2015 \\
\longrightarrow \text { Temperature } 2015\end{array}$ \\
\hline
\end{tabular}

Figure 1. Accumulated rainfall and monthly average temperatures in 2013, 2014, and 2015 in the municipality of Antonina, in the coast of the state of Paraná, Brazil. Data obtained from the weather station of Sistema Meteorológico do Paraná (Simepar). 
Cochran's test. The analysis of variance was performed, and significant data were explored by the polynomial regression analysis, adjusting the equation based on the regression coefficient and its significance of $5 \%$ probability. For the analyses, the statistical software Assistat, version 7.7 beta, was used (Silva, 2015).

\section{Results and Discussion}

In 2013, plants began their reproductive cycle with the emission of floral buds, followed by the start of anthesis. However, there was a high index of flower abortion and fall of fruit at early development stages, with no late flowering. The lack of fruit production in 2013 was probably related to the occurrence of droughts from February to April, since, in the following years, the flowering peak occurred in February, with rainfall accumulation of $1,031 \mathrm{~mm}$ in 2014 and of $1,065.4 \mathrm{~mm}$ in 2015, very different from that of $563.2 \mathrm{~mm}$ in 2013 in the same period (Figure 1). This is an indicative that the rainfall volume in the first months of the year may be determinant in consolidating the reproductive cycle of this plant species.

In 2014 and 2015, considered the monitoring years, plants completed the full cycle of fruit ripening. However, in 2015, this cycle was slightly longer. One reason may be the occurrence of the anthesis of flowers (characterized by $50 \%$ or more flowered plants) approximately ten days earlier than in 2014, which extended the whole cycle, slowing the development of the embryo. Another may be related to slightly lower amount of rainfall in 2014 compared with 2015 (Figure 1). There was an increase of $264.6 \mathrm{~mm}$ in the accumulated rainfall from October 2014 to September 2015, in comparison with the period from October 2013 to September 2014, when the 2014 reproductive cycle ended and the plant started a new vegetative cycle, preparing for the next reproductive cycle; therefore, the plant probably extended its reproductive cycle in 2015 due to the higher water availability. Lamarca et al. (2013), while studying the ripening process of E. pyriformis recalcitrant seeds under different climate conditions, also observed a reduced reproductive cycle with decreased rainfall.

The color of guanandi fruit during the ripening process (Figure 2) was marked by the gradual alteration in the shade of the epicarp (most external layer of the fruit), from a lighter and homogenous green to a darker one, which became predominant at 110 days after anthesis (DAA) and remained until the end of the process. As time passed, in the second month of harvest but more noticeably from 110 DAA onwards, the exposure of fruit to the environment caused small dark spots on the epicarp. These spots may be due to friction damage by wind action or by predation attempts from insects; when this happens, a collector that is not very experienced may conclude
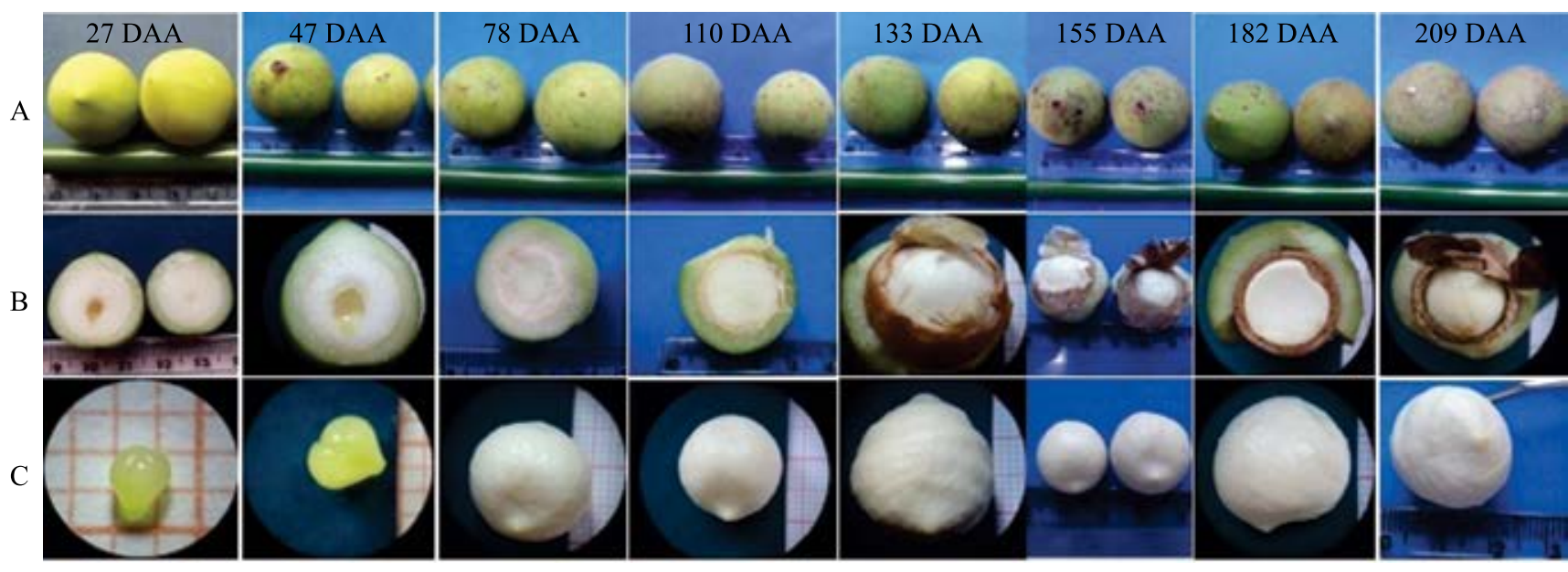

Figure 2. Development of guanandi (Calophyllum brasiliense) fruit and embryos. A, whole fruit; B, cut fruit, internal visualization; and C, embryos. Representation of the development sequence from 27 to 209 days after anthesis (DAA), in 2014. 
that the fruit are ready for harvesting, supposing they are in senescence because of their darker appearance.

The internal morphology of the fruit at the initial stages from 27 to 47 DAA showed that the endocarp, which is the inner layer of the pericarp surrounding the seed, presented a yellowish line (Figures 2 and 3). More internally, starting from the endocarp, it was possible to visualize the cellular endosperm (solid), a larger layer formed by a white mass of cells with cell walls; and, closer to the center, both the nuclear endosperm (liquid), formed by cells with free nucleus, which characterizes the helobial endosperm (Carvalho \& Nakagawa, 2012), and a small, translucent, and greenish-colored embryo involved by the endosperm. At the initial development stages, it was not possible to identify the tegument, because it is adherent to the endocarp.

From the following stage (78 DAA) onwards, only the cellular endosperm surrounding the embryo showed a more fibrous aspect (Figures 2 and 3). The endocarp became more yellowish and firm, whereas the embryo appeared more developed, non-translucent, and cream colored.

At 110 and 133 DAA, the endosperm became a small whitish layer (Figure 2), being practically consumed during the development of the embryo, which occupied almost the entire internal cavity. The endocarp became firmer and changed to a color between intense yellow and light brown; from 133 DAA, it was possible to observe more clearly the presence of a yellow-colored tegument, below the endocarp.

At 155 DAA (Figure 2), there was a predominance of fruit with internal aspects similar to those of the previous stage (133 DAA); however, some fruit presented an endocarp with a darker brown shade and the internal face of the tegument with the same brown color. The endosperm was not observed, since, starting at this stage, it was totally consumed by the embryo. At 182 DAA, fruit with a dark brown endocarp and tegument became the most frequent.

At 209 DAA, when harvests ended and most fruit had already detached from the plants, the fruit pulp appeared loosely adherent to the endocarp and all fruit presented dark brown endocarp and tegument, with the embryo being loosely adherent to these structures (Figure 2).

At the later stages (182 and 209 DAA), unlike at the previous ones, the pulp had a slightly sweeter taste. A great amount of partially eaten fruit, probably by bats, was also found fallen on the ground, close to the monitored trees. Therefore, it is possible to deduce that the dispersion of fruit and seeds by fauna begins at these stages, making it the most proper time to harvest seeds.

There are reports in the literature indicating the participation of animals, such as bats from the Artibeus genus (Mello et al., 2005), in guanandi seed dispersal.
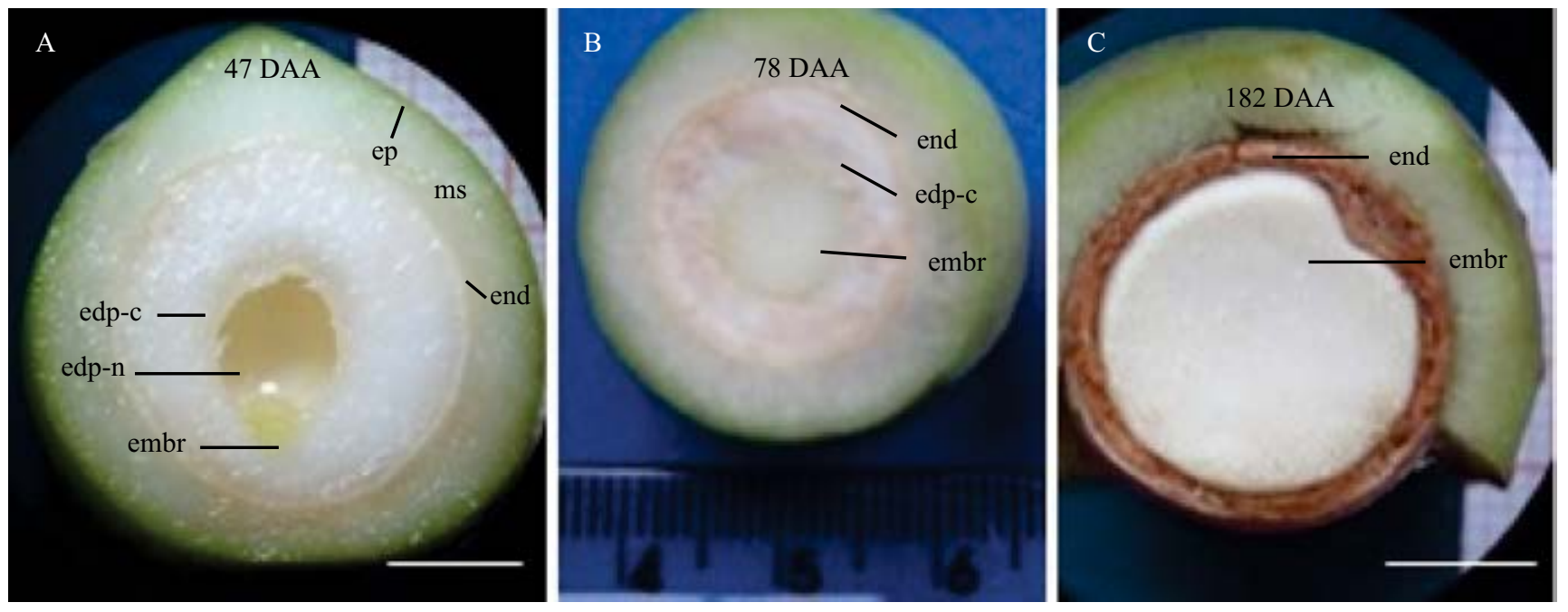

Figure 3. Guanandi (Calophyllum brasiliense) fruit in a longitudinal cut. A and B, fruit at initial development stages, with the presence of the helobial (nuclear and cellular) and sole cellular endosperms, respectively; and C, fruit at the end of the ripening process, without the presence of the endosperm. ep, epicarp; ms, mesocarp; end, endocarp; embr, embryo; edp-n, nuclear endosperm; and edp-c, cellular endosperm. White bars represent a $10-\mathrm{mm}$ scale. 
However, studies combining this information with the specific interests of the seed technology area are still necessary, because, when a species is explored for commercial purposes, quality seeds should be obtained regardless of the action of fauna, especially since, in many cases, there may be a conflict of interests between seed producers and natural dispersers.

In several studies, the color of fruit and seed teguments was considered as a criteria to monitor the ripening process and to determine the proper time to harvest E. uniflora (Avila et al., 2009), Erythrina variegata L. (Matheus et al., 2011), E. pyriformis (Lamarca et al., 2013), and Copernicia hospita Mart. (Pereira et al., 2014). In the case of guanandi, the changes in the external color of fruit were not a good criterion for determining harvesting time, since no color alterations were observed starting at $110 \mathrm{DAA}$ (Figure 2), which is the stage corresponding to half of the whole ripening period. However, the color of endocarp and of the internal face of the tegument (dark brown at the final stages), together with the easy detachment of the pulp from the endocarp and of the embryo from the endocarp and tegument (Figures $2 \mathrm{~B}$ and $3 \mathrm{C}$ ), is a good indicator to identify the harvesting time of seeds. Therefore, before harvesting a great amount of fruit, the collector should identify the internal characteristics of a sample in order to verify if the seeds are ready or not to be harvested. This procedure is viable when there are no significant variations in ripening among the fruit of a same plant, which seems to be a characteristic of guanandi; in the present study, there were no significant differences in the development of fruit and embryos from the same tree, and the most evident differences occurred at the beginning of embryo formation and not at the end of the reproductive cycle.

At the first development stages in 2014 (27 to 47 DAA) and in 2015 (28 to 76 DAA), the embryo could only be observed with the aid of a stereomicroscope (Figure 2). When visualized, the embryos measured approximately 1.0 and $5.0 \mathrm{~mm}$ vertical and horizontal diameters, respectively. Due to their small size, it was not possible to evaluate their physical and physiological characteristics in these periods; therefore, the analyses were performed starting at 78 DAA in 2014 and at 113 DAA in 2015.

Guanandi fruit and seeds, during both monitoring years, presented maximum vertical (Dv) and horizontal
(Dh) diameters close to the middle of the ripening process (Figure 4), which is commonly observed (Barbosa et al., 2015). Their size only decreased after three or four harvests, usually due to the water losses at the end of the ripening stage (Avila et al., 2009; Carvalho \& Nakagawa, 2012; Lamarca et al., 2013).

Because they are recalcitrant, guanandi seeds are not subjected to an intense drying process during ripening. It should be pointed out that the initial moisture content of these seeds is normally quite elevated, close to $80 \%$ on a wet basis, and remains unchanged for a period of time; at this stage, the dry matter mass also does not change because the cells are going through intense division and expansion (Marcos-Filho, 2015). During the first harvests, the moisture content of the embryos could not be measured due to their much reduced size; however, at the end of the ripening process, their initial moisture content was close to 82 and $90 \%$, decreasing to 39 and $47 \%$, respectively, in 2014 and 2015 (Figure 4). The dry matter mass of fruit (whose composition includes the embryo) was determined since the first harvest, showing stability, followed by a period of increase and then by a new tendency of stabilization in the last harvests. Once it was possible to measure the embryos individually, there was a continuous increase in their dry matter mass until stabilization in the last three harvests in 2014 and in the last two in 2015.

Water loss of guanandi embryos, due to the recalcitrant behavior of the seeds, was more constant and accentuated at the initial ripening stages, with values between 40 and $46 \%$ from the beginning to the end of ripening, when it was almost stable (Figure 4). Yu \& Chen (2012) also verified a more accentuated decrease in the moisture content of Aesculus chinensis Bunge seeds during the first stages of the ripening process, with later stabilization. Marcos-Filho (2015) highlighted that water loss is more gradual in orthodox seeds at the beginning of their development and is accentuated after they reach the maximum accumulation of dry matter, preparing to later enter the quiescence or dormancy state; however, this does not occur with recalcitrant seeds, which detach from the mother plant with a high moisture index and are ready to germinate.

The maximum accumulation of dry matter was reached at 155 DAA in 2014, when there was no more significant transfer of reserves from the mother plant to the embryos (Figure 4). However, in 2015, 


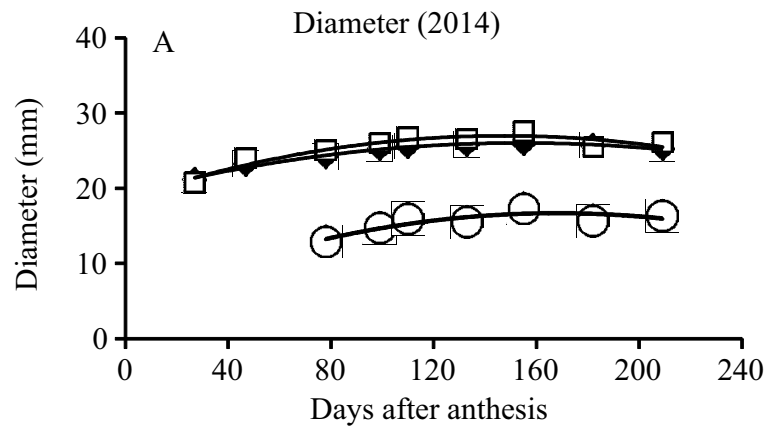

- Dv fruits $\quad\left(\mathrm{Y}=19.2+0.088 \mathrm{x}-0.00029 \mathrm{x}^{2} ; \mathrm{R}^{2}=0.98^{* *}\right)$

$\square$ Dh fruits $\quad\left(\mathrm{Y}=18.6+0.11 \mathrm{x}-0.00039 \mathrm{x}^{2} ; \mathrm{R}^{2}=0.89 * *\right)$

\ Dv embryos $\left(\mathrm{Y}=4.7+0.142 \mathrm{x}-0.00042 \mathrm{x}^{2} ; \mathrm{R}^{2}=0.79 * *\right)$

O Dh embryos $\left(\mathrm{Y}=4.6+0.14 \mathrm{x}-0.0004 \mathrm{x}^{2} ; \mathrm{R}^{2}=0.78^{* *}\right)$

Dry matter mass and moisture content (2014)

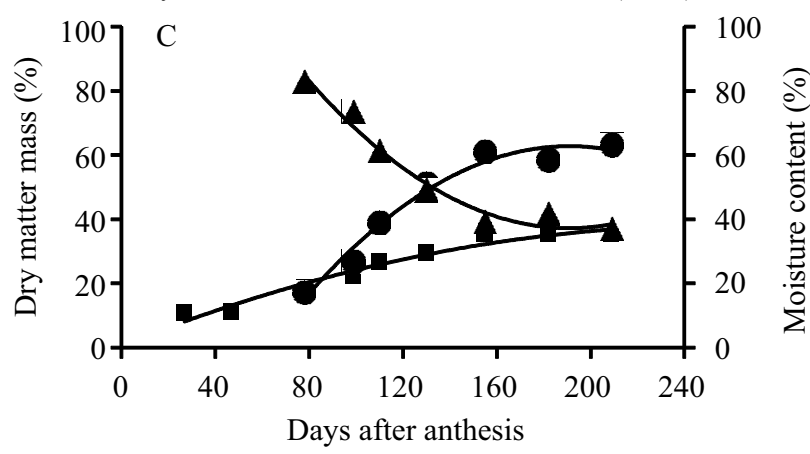

Ms fruit $\quad\left(\mathrm{Y}=0.69+0.29 \mathrm{x}-0.0005 \mathrm{x}^{2} ; \mathrm{R}^{2}=0.96 * *\right)$

- Ms embryo (Y=-73+1.4x-0.003x $\left.; \mathrm{R}^{2}=0.97 * *\right)$

\ Ta embryo $\left(\mathrm{Y}=-173+1.4 \mathrm{x}-0.003 \mathrm{x}^{2} ; \mathrm{R}^{2}=0.97 * *\right)$

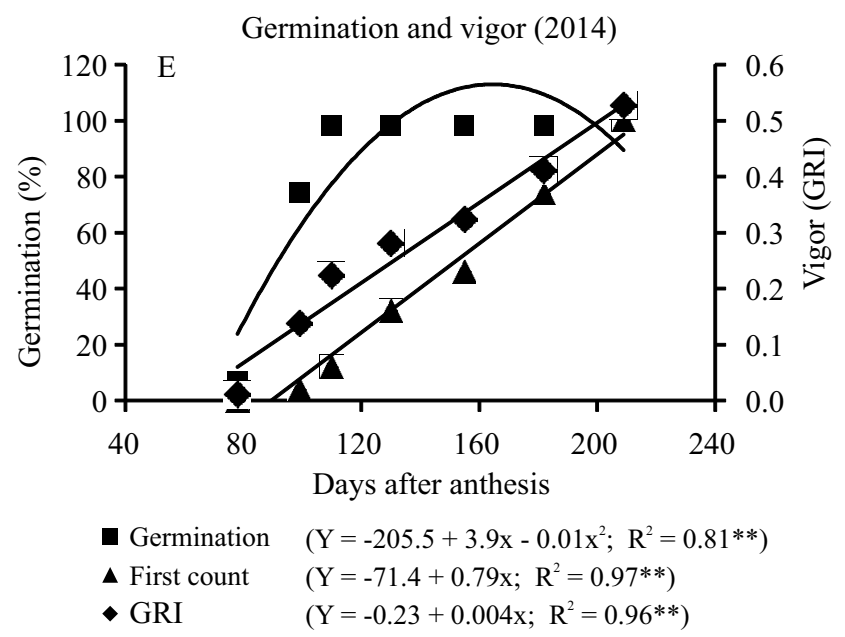

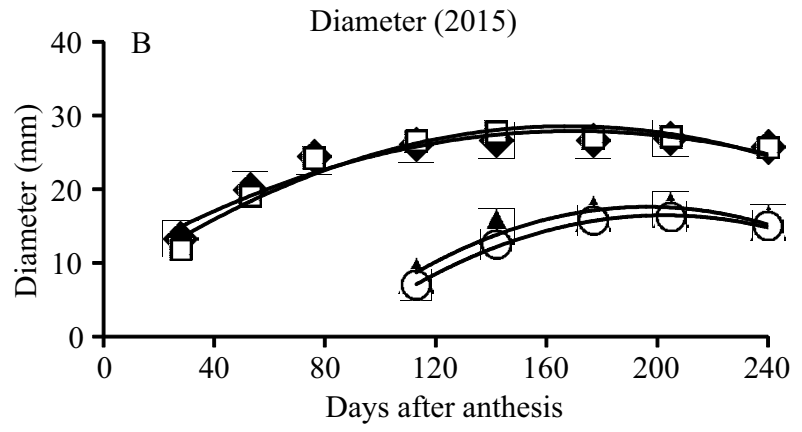

- Dv fruits $\quad\left(\mathrm{Y}=9.3+0.22 \mathrm{x}-0.00064 \mathrm{x}^{2} ; \mathrm{R}^{2}=0.92 * *\right)$

$\square$ Dh fruits $\quad\left(\mathrm{Y}=5.2+0.3 \mathrm{x}-0.00097 \mathrm{x}^{2} ; \mathrm{R}^{2}=0.96^{* *}\right)$

$\Delta$ Dv embryos $\left(\mathrm{Y}=-31.7+0.5 \mathrm{x}-0.001 \mathrm{x}^{2} ; \mathrm{R}^{2}=0.97 * *\right)$

O Dh embryos $\quad\left(\mathrm{Y}=-31.6+0.5 \mathrm{x}-0.001 \mathrm{x}^{2} ; \mathrm{R}^{2}=0.99 * *\right)$

Dry matter mass and moisture content (2015)

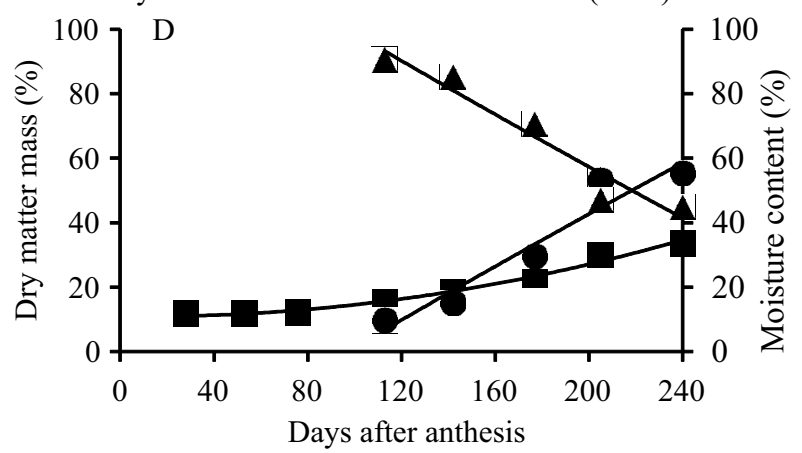

- Ms fruit $\quad\left(\mathrm{Y}=10.9-0.009 \mathrm{x}-0.0004 \mathrm{x}^{2} ; \mathrm{R}^{2}=0.98^{* *}\right)$

- Ms embryo $\left(\mathrm{Y}=-39+0.41 \mathrm{x} ; \mathrm{R}^{2}=0.93\right)^{* *}$

\ Ta embryo $\left(\mathrm{Y}=-139+0.41 \mathrm{x} ; \mathrm{R}^{2}=0.93\right)^{* *}$

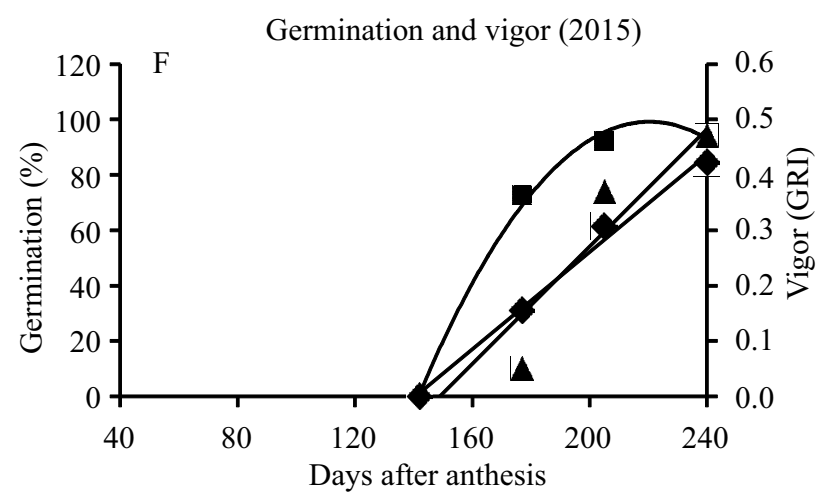

Germination $\left(\mathrm{Y}=-677.2+7.04 \mathrm{x}-0.015 \mathrm{x}^{2} ; \mathrm{R}^{2}=0.99^{* *}\right)$

\ First Count $\quad\left(\mathrm{Y}=-157.8+1.06 \mathrm{x} ; \mathrm{R}^{2}=0.90^{* *}\right)$

- GRI $\left(\mathrm{Y}=-0.62+0.004 \mathrm{x} ; \mathrm{R}^{2}=0.99 * *\right)$

Figure 4. Development of guanandi (Calophyllum brasiliense) fruit and seeds during the ripening process, in 2014 and 2015. A and B, diameter of fruit and embryos, respectively; C and D, dry matter mass of fruit and embryos; and $\mathrm{E}$ and F, germination, first count, and germination rate index (GRI) of embryos. Dv, vertical diameter; Dh, horizontal diameter; Ms, dry matter mass; and Ta, moisture content. **Significant at $1 \%$ probability. 
with the delay in the ripening process, the maximum accumulation of dry matter in the embryos only occurred at 205 DAA.

At 99 DAA in 2014 and 177 DAA in 2015, 74 and $73 \%$ of the germinated embryos grew into normal seedlings, respectively (Figure 4). In the following harvests, no significant differences were observed in the number of germinated embryos, which became stable with a total of normal seedlings between 98 and $100 \%$ in 2014 and 92 and $94 \%$ in 2015.

Germination stabilization in 2014 was not synchronized with the maximum accumulation of dry matter mass, since total germination had already reached $98 \%$ at 110 DAA (Figure 4 ) and the maximum accumulation only started at 155 DAA. However, in 2015, the stabilization of both germination and reserve accumulation was observed from 205 DAA onwards. In both years, such stabilization was not found for seed vigor, based on the speed index and the first germination count, which increased and reached maximum values in the last harvest.

It should be noted that, in some species, the maximum accumulation of dry matter mass does not always coincide with the physiological ripeness of seeds, which still need to reach their physiological potential. This may be the case in species producing fleshy fruit (Marcos-Filho, 2015), which could explain the results obtained for guanandi, which presents a fleshy pulp.

Similar results were found by other authors. In a study on the ripening of E. uniflora seeds, a species with recalcitrant behavior like that of guanandi, Avila et al. (2009) also did not report synchrony between the beginning of the germinating power of the seeds and the maximum accumulation of dry matter mass - seeds reached $86 \%$ germination at 42 DAA and dry matter mass stabilization occurred from 63 DAA onwards. In Nihoa fan palm seeds (Pritchardia remota Becc.), a recalcitrant species that presents endospermic reserves, Pérez et al. (2012) found that the process of dry matter mass accumulation of the embryo was desynchronized with that of the endosperm and the fruit, reaching maximum accumulation at 250 DAA, whereas endosperm and fruit did so at 340 DAA. The maximum germination and vigor of the endosperm and fruit were only reached between 340 and 400 DAA, and the last harvest and evaluation point were marked by the fall of the fruit.
The desynchronization between physiological ripeness and maximum accumulation of dry matter, however, is not an exclusive characteristic of species with recalcitrant seeds, also being verified in orthodox species. Nakagawa et al. (2010) concluded that copperpod (Peltophorum dubium Taub.) seeds did not show germination capacity in spite of reaching their maximum dry matter mass, i.e., they stopped receiving photoassimilates from the mother plant before reaching physiological ripeness; for this reason, according to the authors, these seeds need to undergo a drying process.

In the present study, the development of guanandi fruit and seeds in the studied region started in February, when $50 \%$ of the flowers from the selected plant population were in anthesis. In March and April, the fruit were beginning to develop and the presence of the helobial endosperm was observed; however, it was quickly consumed in the initial development stages of the embryo, with the permanence of the sole solid endosperm starting in May. Fruit and seeds reached maximum development between August and September, and the natural dispersion ended the reproductive cycle in October.

\section{Conclusions}

1. The ripening of guanandi (Calophyllum brasiliense) seeds, in the coast of the state of Paraná, Brazil, lasts from 200 to 240 days, with the peak of flower anthesis in February and dispersion of fruit and seeds in October.

2. The maximum accumulation of the dry matter mass of seeds is not synchronized with their maximum physiological potential.

3. The germination potential of seeds is reached close to the middle of the ripening process and the maximum vigor at the end.

4. Changes in the external color of guanandi fruit have no relation with harvesting time, since there are no more color changes starting from 110 days after anthesis.

5. The morphological characteristics related to harvesting time are fruit pulp and embryo weakly adherent to the endocarp and tegument, respectively, as well as the dark brown color of these tissues.

\section{References}

AVILA, A.L. de; ARGENTA, M.da S.; MUNIZ, M.F.B.; POLETO, I.; BLUME, E. Maturação fisiológica e coleta de sementes de 
Eugenia uniflora L. (pitanga), Santa Maria, RS. Ciência Florestal, v.19, p.61-68, 2009. DOI: 10.5902/19805098420.

BARBOSA, J.M.; RODRIGUES, M.A.; BARBÉRIO, M.; ARAUJO, A.C.F.B. Maturação de sementes de espécies florestais tropicais. In: PIÑA-RODRIGUES, F.C.M.; FIGLIOLIA, M.B.; SILVA, A. da. Sementes florestais tropicais: da ecologia à produção. Londrina: ABRATES, 2015. p.180-189.

BRASIL. Ministério da Agricultura, Pecuária e Abastecimento. Regras para análise de sementes. Brasília, 2009. 395p.

CACCERE, R.; TEIXEIRA, S.P.; CENTENO, D.C.; FIGUEIREDO-RIBEIRO, R. de C.L.; BRAGA, M.R. Metabolic and structural changes during early maturation of Inga vera seeds are consistent with the lack of a desiccation phase. Journal of Plant Physiology, v.170, p.791-800, 2013. DOI: 10.1016/j. jplph.2013.01.002.

CARVALHO, M.N. de; NAKAGAWA, J. (Ed.). Sementes: ciência, tecnologia e produção. 5.ed. Jaboticabal: Funep, 2012. 590p.

CARVALHO, L.R. de; SILVA, E.A.A. da; DAVIDE, A.C. Classificação de sementes florestais quanto ao comportamento no armazenamento. Revista Brasileira de Sementes, v.28, p.15-25, 2006. DOI: 10.1590/S0101-31222006000200003.

LAMARCA, E.V.; PRATAVIEIRA, J.S.; BORGES, I.F.; DELGADO, L.F.; TEIXEIRA, C.C.; CAMARGO, M.B.P. de; FARIA, J.M.R.; BARBEDO, C.J. Maturation of Eugenia pyriformis seeds under different hydric and thermal conditions. Anais da Academia Brasileira de Ciências, v.85, p.223-233, 2013. DOI: $10.1590 / \mathrm{S} 0001-37652013005000006$.

MAGUIRE, J.D. Speed of germination - aid in selection and evaluation for seedling emergence and vigor. Crop Science, v.2, p.176-177, 1962. DOI: 10.2135/ cropsci1962.0011183X000200020033x.

MARCOS-FILHO, J. Fisiologia de sementes de plantas cultivadas. 2.ed. Londrina: ABRATES, 2015. 660p.

MATA, M.F.; SILVA, K.B.; BRUNO, R. de L.A.; FELIZ, L.P.; MEDEIROS FILHO, S.; ALVES, E.U. Maturação fisiológica de sementes de ingazeiro (Inga striata) Benth. Semina: Ciências Agrárias, v.34, p.549-566, 2013. DOI: 10.5433/1679-0359.2013v3 $4 \mathrm{n} 2 \mathrm{p} 549$

MATHEUS, M.T.; LOPES, J.C.; CORRÊA, N.B. Maturação fisiológica de sementes de Erythrina variegata L. Ciência Florestal, v.21, p.619-627, 2011. DOI: 10.5902/198050984507.

MELLO, M.A.R.; LEINER, N.O.; GUIMARÃES JR., P.R.; JORDANO, P. Size-based fruit selection of Calophyllum brasiliense (Clusiaceae) by bats of the genus Artibeus (Phyllostomidae) in a Restinga area, southeastern Brazil. Acta Chiropterologica, v.7, p.179-182, 2005. DOI: 10.3161/1733-5329(2005)7[179:SFSOCB]2.0.CO;2.

NAKAGAWA, J.; MORI, E.S.; PINTO, C. da S.; FERNANDES, K.H.P.; SEKI, M.S.; MENEGHETTI, R.A. Maturação e secagem de sementes de Peltophorum dubium (Spreng.) Taubert (canafístula). Revista Árvore, v.34, p.49-56, 2010. DOI: 10.1590/ S0100-67622010000100006.
NERY, F.C.; ALVARENGA, A.A. de; JUSTO, C.F.; DOUSSEAU, S.; VIEIRA, C.V. Efeito da temperatura e do tegumento na germinação de sementes de Calophyllum brasiliense. Ciência e Agrotecnologia, v.31, p.1872-1877, 2007. DOI: 10.1590/S141370542007000600041 .

NOLDIN, V.F.; ISAIAS, D.B.; CECHINEL FILHO, V. Gênero Calophyllum: importância química e farmacológica. Química Nova, v.29, p.549-554, 2006. DOI: 10.1590/S010040422006000300025 .

OLIVEIRA, V.C. de; JOLY, C.A. Flooding tolerance of Calophyllum brasiliense Camb. (Clusiaceae): morphological, physiological and growth responses. Trees, v.24, p.185-193, 2010. DOI: 10.1007/s00468-009-0392-2.

PEREIRA, D. de S.; SOUSA, J.E.S.; PEREIRA, M. de S.; GONÇALVES, N.R.; BEZERRA, A.M.E. Influência da maturação dos frutos na emergência e crescimento inicial de Copernicia hospita Mart. - Arecaceae. Revista Ciência Agronômica, v.45, p.214-220, 2014. DOI: 10.1590/S1806-66902014000100025.

PÉREZ, H.E.; HILL, L.M.; WALTERS, C. An analysis of embryo development in palm: interactions between dry matter accumulation and water relations in Pritchardia remota (Arecaceae). Seed Science Research, v.22, p.97-111, 2012. DOI: 10.1017/S0960258511000523.

SCHULTZ, J. Calophyllum brasiliense: Olandi. In: CORADIN, L.; SIMINSKI, A.; REIS, A. (Ed.). Espécies nativas da flora brasileira de valor econômico atual ou potencial: plantas para $\mathrm{O}$ futuro - Região Sul. Brasília: MMA, 2011. p.440-443.

SILVA, F. de A.S. e. ASSISTAT - Assistência Estatística: [versão 7.7 beta]. Campina Grande: Universidade Federal de Campina Grande, 2015. Available at: <http://www.assistat.com/>. Accessed on: Apr. 12015.

SILVA, R.C. da; VIEIRA, E.S.N.; PANOBIANCO, M. Técnicas para superação da dormência de sementes de guanandi. Pesquisa Agropecuária Brasileira, v.49, p.719-727, 2014. DOI: 10.1590/ S0100-204X2014000900008.

SOROL, C.B.; CARVAJAL, S.; CALONGA SOLÍS, V.; LUCÍA GONZÁLEZ, N.; ECKERS, F. Bases para la conservación de las semillas de Calophyllum brasiliense (Calophyllaceae). Boletín de la Sociedad Argentina de Botánica, v.50, p.93-106, 2015.

VÁSQUEZ-CARBALLO, W.; THOMSEN, K.A.; JØKER, D. Desiccation and storage of seeds of Astronium graveolens and Calophyllum brasiliense, two native species of Costa Rica. In: SACANDÉ, M.; JØKER, D.; DULLOO, M.E.; THOMSEN, K.A. (Ed.). Comparative storage biology of tropical tree seeds. Rome: International Plant Genetic Resources Institute, 2004. p.285-294.

YU, F.; CHEN, S. Morphological and biochemical changes of Aesculus chinensis seeds in the process of maturation. New Forests, v.43, p.429-440, 2012. DOI: 10.1007/s11056-011-9289-1.

$\overline{\text { Received on October 15, } 2016 \text { and accepted on June 14, } 2017}$ 